\title{
The Potential of Halal Food as A Driver of the Economic Development in Regional Community
}

\author{
Hisam Ahyani ${ }^{1}$, Muntaha Mahfud², Rohmat Waluyo ${ }^{3}$, Widadatul Ulya ${ }^{4}$, \\ Muharir $^{5}$
}

\begin{abstract}
Affiliation
${ }^{1}$ Doctoral Program in Islamic Law, Consentration of Sharia Economic Law, Universitas Islam Negeri Sunan Gunung Djati, Bandung, 1, 2, 3, 4, 5Sekolah Tinggi Agama Islam Miftahul Huda AI Azhar (STAIMA) Kota Banjar.

\section{Correspondence}

Hisam Ahyani. Sekolah Tinggi Agama Islam Miftahul Huda Al Azhar (STAIMA) Kota Banjar, J. Pesantren No.2 Kujangsari, Langensari, Banjar City, West Java 46324, Indonesia. Email: hisamahyani@gmail.com
\end{abstract}

\begin{abstract}
This study aims to describe local specialties that have the potential to become halal food in order to boost the economy of local communities in three areas including Lakbok subdistrict, Kedungreja sub-district, and Wangon sub-district. In the halal food sector or halal food in Indonesia, especiallyin the Era of the Industrial Revolution4.0, as it is now, it has become a necessity. This research method uses field studies with data obtained from observations and interviews and documentation. The results showed that halal food in the three sub-districts was able to boost the economy of the people in the area, as evidenced by the sufficient daily needs needed by the people in the three sub-districts. Various foods that can be used as halal food in these three sub-districts are varied, including cassava based chips, Tape, Cimplung or Kulub and Ciu, from soybean ingredients including Sule and Tempe Mendoan, from legen ingredients (coconut juice) can be made into Javanese sugar / brown sugar and can also be used as a mixture for making apem / cake foods. However, from the potential of halal food, some are already labeled halal and some are not labeled halal. This is what makes halal food in these three sub-districts less attractive to consumers.
\end{abstract}

Keywords: Industry; Halal Food; Tourism; Economic Development.

Article Information

Submitted 30 Januari 2021 | Revised 19 A pril 2021 | Accepted 3 May 2021

Recommended Citation: Ahyani, H., Mahfud, M., Waluyo, R., Ulya, W., Muharir. (2020). The Potential of Halal Food as A Driver of the Economic Development in Regional Community. Jurnal Pariwisata Terapan, 4 (2), 163-182.

https://doi.org/10.22146/jpt.63771 


\section{Introduction}

The potential of halal food as an ecosystem that drives the economy of regional communities in general in Indonesia needs to be developed in order to make Indonesia the world's halal center. This was conveyed by (Thohir, 2021) as Minister of BUMN and Chair of the Sharia Economic Community (MES) at the inauguration of the Nurul Quran Islamic Boarding School Pertashop in Surusunda Village, Karangpucung District, Cilacap Regency (Republika.co.id, 2021). The potential of the halal industry that can be used or developed by Indonesia includes halal tourism. Where Indonesia has great potential to continue to contribute to increasing state income through a Muslim Friendly tourism sector (Brodjonegoro, 2018).

In addition, traditional regional specialties also need to be developed in order to boost the economy of the local community. According to Mr. Tatto Suwarto Pamuji as Regent of Cilacap, he recommended that food that has become the hallmark of cilacap, which until now still exists in the Cilacap Regency Society of Central Java, Indonesia, according to Mr. unique potential in the Cilacap district, of course, by processing it not only by boiling it, but by using other methods or packaging. This is in order to develop food potential in Cilacap district as an economic driver of the local community (Mulyono, 2018; humas.cilacapkab.go.id). In Indonesia, according to the Governor of Bank Indonesia Agus Martowardojo, after opening the Regional Sharia Economic Festival in the province of Central Java (Semarang), he said that the growing potential related to the "halal food industry" in Indonesia has reached 167 billion (US dollars), or in the range of approximately 2.3 trillion if we look at the exchange rate in 2016 , for that we must continue to develop this halal food industry. If this potential is left unchecked, it will become a threat and besides that Indonesia also has a lot of potential for the halal food industry, where the majority of Indonesia is Muslim (Nurdin and Auliani; Kompas.com, 2018).

In the tourism sector, which has become the fastest growing sector in Indonesia in particular, in the last few decades. Tourism development is now also moving into rural areas by raising local wisdom in each place, for example, Brajan Tourism Village, in Sleman Regency, Yogyakarta Province, which is included in the developing category in the tourism sector (Paskasari, 2020). Likewise (Ahdiati, 2020) related to the development of local identity "cablaka or straightforward language typical of regional languages" which reflects local wisdom in tourism development which aims to maximize local values in developing the area in Banyumas Regency, Central Java Province.

The values of divine monotheism or in Arabic rububiyyah-uluhiyyah Qardawi argues, as quoted by Muhammad Djakfar in his book "halal tourism", it is explained that Islamic economics is basically the prime cause in other character values. This is because in the rububiyyah position it precedes the order of the other positions. This shows how important the value of rububiyyah is among other derived values (Djakfar, 2017) in research (Zahrah \& Fawaid, 2019) related to halal food. Research (Ali, 2016) on the Concept of Halal Food in a Sharia Perspective and Product Responsibility for the Halal Industry. Whereas Sharia provisions regarding food, drink, and halal and haram goods are an integral part of Islamic teachings. Halal and haram food has also become a necessity related to the comfort and safety of Muslims as the largest consumers in Indonesia. This need must be enforced by the halal industry. Interestingly again (Nazihah \& Arifin, 2020) explained in their research that 
Islam is a religion that regulates all human aspects. Muslims in Indonesia generally focus on the discussion of fiqh of worship only, but do not pay much attention to the aspects of its muamalah fiqh. The habit of consuming without considering "halal and haram", or anything "materialistic" will only cause temporary satisfaction. This means not only in the realm of "food". But everything that humans want to develop, whether from science and technology, or even creativity, even innovation, will bring damage or danger to human life, society, and the natural surroundings in this world.

Halal and haram are important issues for Muslims, especially when talking about food that concerns people's needs. In an effort to protect the public against food products, joint efforts are needed, especially those produced to certify the halal label through the LPPOM which is endorsed by the MUI (Indonesian Ulema Council). Thus the "receptie theory" which states that the applicable law for Muslims is "their respective customary law". With the existence of certification and "halal labeling", for example, which aim to provide "inner peace" to every Muslim and provide "peace of mind". producing "for producers and also to provide business motivation in terms of reaping profits in promising businesses (Sah, 2018).

Similar research by (Sayyidatunisa et al., 2020) related to the rapid development in the "halal industry" sector which is in line with the present era, namely the 4.0 era, shows that in terms of the processing system demanded by the presence of digitalization in every line of industry, the sector is no exception. food, especially halal food. Regarding halal food, it is a law that is identical to the Islamic religion, so the level of Halalness of a food is very important to pay attention to, because it shows that it is permissible for a food to be consumed by a Muslim. So of course it is very necessary to have a media that can make it easier for every Muslim to ensure the halalness of what he will consume, where later the media can be collaborated with the development of existing technological sophistication so that it can make it easier for every user of the media. In this study the authors used a platform design toolkit which then produced an application called "Mahal's" (Halal Scan Food) as a solution. Through this application, it is hoped that it can make it easier for each user to find out the halalness of what he will consume, with this application it can also convince users of what halal food they will consume, and make it easier for users to find out the locations that provide halal food that has been certified.

Indonesia has become famous in parts of the world where it is said that Indonesia has the majority of the world's largest Muslim population. So in this case the demand for "halal certified products" has always experienced a significant increase in public awareness when it comes to the issue of "halal products". Regarding awareness of the consumption of "halal food" for students at the junior high school level, as well as in the realm of "student behavior" in choosing halal and healthy food by paying attention to aspects of halalness such as the halal logo and the composition of food ingredients (Dewi, 2020). In several subdistricts in Semarang City, Central Java, the potential is related to food stalls and industry. The research launched by (Widayat et al., 2020) was conducted in Tembalang District, which has "food stalls and the culinary industry". In terms of the awareness of the Muslim community, Tembalang sub-district is still low.

Halal food in the lakbok sub-district, Ciamis district, is the focus of this study because not all halal food in this sub-district has given halal adhesion to the food products produced, but 
people consider the food produced is included in the halal food category (Hamid \& Tusiem, 2021). Based on the results of field observations with Mr. (Kasmuri \& Fikri, 2021), residents of the lakbok sub-district explained about the halal food products they process, which includes ingredients from cassava (budin in Javanese), this food can also be made into Kulub / Cimplung legit. In addition, soybean ingredients can be used as food for "Tempe Mendoan". In addition, Banana Chips are also a mainstay in improving the economy in Lakbok District, but all of these foods have not all put a halal label on the products produced. Another resident (Hamid \& Tusiem, 2021) explained that the brown sugar food product is produced from boiled coconut juice. He explained that in the first manufact uring process he took coconut palm water directly from superior coconut trees by means of menderes, or commonly referred to as "Sadap Badeg" or taking coconut tree juice that grows well in Lakbok District. Basically, food managers put forward their halal production standards which are based on Islamic law. Subjects that can cause problems or in this case the researcher uses the term subhat which is the standard for processing raw materials. For example, the fish used is fish that is dead and may seem rotten (poor quality), or the use of ingredients such as preservatives that do not use BPPOM standards. This means that in the lakbok sub-district, related to halal food, not all of them provide halal adhesion to the products produced.

As for halal food in the wangon sub-district, Banyumas district, the results of its food products are in the form of drinks in the form of Ciu, which this ciu will be used as a hand sanitizer to prevent the entry of the corona virus, and to make a high selling value and is expected to improve the standard of living of the community of producers. ciu in Banyumas (Rempi, 2020) in (Anugrah, 2020) news.detik.com. From the potential for halal food in the wangon sub-district, there are several trends, namely when the price of raw materials increases, the quality of the product decreases because the owner does not want to increase the price. Meanwhile, related to the halal melting of food in the wangon subdistrict, Banyumas district, it has not been able to increase the rating in market share, for example in this ciu drink. This is what makes researchers interested in that the halal melting in ciu drinks has no effect on the rating in market share, so this is what is interesting, where ciu is related to its halalness, there are still pros and cons among some ulama circles. In Indonesia itself, there are many types of processed drinks made from non-grape ingredients that are often consumed by the public, such as Ciu, tape water, tuak, fermentation in zalacca, this is the law of consuming them, there is still the opinion of scholars (Syauqi, 2020).

Based on the results of an interview with (Ifah \& Mahfud, 2021) at his residence in Dusun Kedungdadap RT 004 Rw 001 Rejamulya Village, Kedungreja District, there are several halal foods which include soy-based ingredients which are used as food for daily needs such as "soybeans" and "tempeh triangle", Quail Eggs in order to improve the economy of the local community. However, in the Kedungreja sub-district, related to halal food, not all of them provide a halal labeling of the products produced. This is what makes researchers interested in uncovering the potential of halal food which can be used as an ecosystem driving the economy of the people of Kedungreja sub-district, where halal food needs to be developed in order to make Indonesia the world's halal center. 
In Indonesia itself, which in fact the majority are Muslim, this halal food in research (Farid \& Basri, 2020) needs to be developed by consuming (halal food) food that is good and healthy for the soul, body and mind. Where by eating halal food this makes spiritual intelligence. Likewise in three areas namely Lakbok, Kedungreja, and Wangon sub-districts which have the potential for "halal food" which can be used as an ecosystem driving the economy of the local community. From the above background, the researcher is interested in describing the potential of halal food as an ecosystem driving the economy of the local community, especially in three sub-districts, including Lakbok, Kedungreja, and Wangon districts. Which is the embodiment of the economy that needs to be developed in order to make Indonesia the world's halal center, one of which is through halal food.

\section{Method}

The research method used is descriptive qualitative research method, namely describing, analyzing existing events or phenomena, or social conditions, where in this case the researcher describes the potential of halal food as an ecosystem driving the economy of the local community. The location of this research was conducted in Lakbok, Kedungreja and Wangon Districts. With data sources obtained from field studies (field research) and various literature that discusses the potential of Halal Food. Sources of data in this study are primary sources including interviews with producers of halal food products in Lakbok, Kedungreja and Wangon Districts and secondary sources of researchers obtained in the form of books or journals and the internet. The data collection technique is carried out by literature study, the data analysis required in the literature study is obtained from a number of references (books, journals, encyclopedias, documents, etc.) which are considered to have a relationship with the problem to be researched and can support problem solving that occurs. The data obtained were analyzed using qualitative data analysis techniques (Ahyani et al., 2021).

The research location on the potential of halal food as an ecosystem driving the economy of the local community was carried out in three districts, including 1) Lakbok District, Ciamis Regency, 2) Kedungreja District, Cilacap Regency and 3) Wangon District, Banyumas Regency. While the limitation of this research discussion is related to the potential of halal food as an ecosystem driving the economy of the people in Lakbok, Kedungreja and Wangon Districts. While the duration of this research is approximately one week, starting from Monday, January 25 to Sunday, January 31, 2021.

\section{Results and Discussion}

\section{Potential of Halal Food in Lakbok District, Ciamis Regency}

The potential for Halal Food or halal food products in Lakbok District, Ciamis Regency, can be seen in the export needs of the resulting Halal Products. So that in the lakbok sub-district in today's challenges (era 4.0) its existence is related to the need for market share, as the results of an interview with (Hamid \& Tusiem, 2021), residents of Lakbok sub-district, Ciamis Regency, he can send his sons and daughters from undergraduate level to doctoral level ), by relying on one of them is entrepreneurship in the production of brown sugar / coconut juice juice obtained in such a way. In addition, there is also a food called "Cimplung Budin" (cimpung is also used as a typical food for Banyumas Central Java), which is made from cassava as the base ingredient which is put into boiled coconut juice (Kasmuri \& Fikri, 2021). However, this cassava is also suitable as a unique snack as well as being the main menu in 
hotels on Baturraden tours, Banyumas after conducting out bond activities at Baturraden tourist sites. Based on the results of an interview with (Kasmuri, 2021) he explained the philosophy of "Budin" (cassava), where Budin stands for Javanese "Sak Budine" which means free movement. With the meaning of moving freely using the discussion of cassava food to be used as several traditional foods such as, Peyeum, Getuk, Growol, cassava flour, Legendar, Ciwel, Karag, Sengkulun, Kueh Bolu, Leper, intil, etc.

Research by (Nurmaydha et al., 2018) in terms of "Islamic tourism" which is a "new trend" of tourism in the world. The opportunities that exist in Islamic tourism have the potential to be very profitable. Islamic tourism in Indonesia itself accommodates many industries, such as "halal food", "halal restaurants", and also "sharia hotels". One of the aspects that must be done in order to make the certification "sharia hotel" run smoothly is a "halal certified" restaurant. Thus, it is possible that in several cities and regencies throughout Indonesia, both halal food must have halal certification from the Indonesian Ulema Council. Regarding Halal Food in Lakbok Subdistrict, as in an interview with Mrs. (Baringah, 2021) she produces Typical Sale Bananas, where these chips have a sweet and savory taste derived from the basic ingredients of "banana siem" instead of other bananas, this is because bananas are suitable for made into crispy and savory chips typical of Lakbok sub-district. In addition, mendoan has also become a popular halal food for the people of lakbok sub-district, one of which is Bapak's shop (Amar, 2021), which sells "mendoan" its typical savory spices from 08.00 WIB to 21.00 WIB.

Lakbok sub-district which is able to bring satisfactory results, besides that young coconut which has medicinal properties is also able to improve the community's economy with a fairly good sales turnover. In addition to young coconut, old coconut is also used as an ingredient for cooking oil production, making the economy of the local community increase, one of which is the coconut picker (Jembrang, Soleh and Taufiq, 2021). Like the original "Kelapa Hijau" kiosk in Ciamis, which belongs to "Kang Agan" (pseudonym "Ateng Dewegan"), which is located on JI. Mr. Iwa Kusuma Soemantri Ciamis.

As stipulated in Chapter I pasa 1 of Law No. 33/2014 concerning the guarantee of halal products, it is explained that "Products" are goods and / or services which are included in 1) food, 2) beverages, 3) drugs, 4) cosmetics, 5) chemical products. ,6) biological products, 7) genetically engineered products, 8) as well as goods that can be utilized (used, used, or utilized) by the community. Furthermore, in Article 1 Point 2 it is explained related to "Halal Products", namely Products that have been declared "halal" in accordance with Islamic law. Article 1 point 3 is related to Halal Product Process, hereinafter abbreviated to (PPH), which is a series of activities to ensure the halalness of a Product which includes the provision of materials, processing, storage, packaging, distribution, sale and presentation of the product. Then in article 1 point 4) related to materials are elements that will be used to make or produce a product. And finally in article 1 point 5) in the case that the Halal Product Guarantee is abbreviated (JPH) is a legal certainty of the halal level of a Product as evidenced by the existence of Halal Certification. Thus, in the lakbok sub-district, halal food in the form of halal food is a great potential for the welfare of the local community's economy through this halal food. Another potential is related to halal food in Degan (Javanese) or commonly called light green coconut, found in Ciamis. 


\section{Potential of Halal Food in Kedungreja District, Cilacap Regency}

In the conception that exists in the halal trend of the food manager, the halal standards of production are based on Islamic law. So that related to the problem, the term subhat appears, namely the standard raw material in processing. For example, the fish used is Trend Halal Food fish in East Kalimantan which is "dead" and may seem rotten or of poor quality. Or the use of preservatives that do not use BPPOM standards. There is a tendency, when the price of raw materials increases, the quality of the product decreases because the owner does not want to increase the price (Hervina, 2017).

Based on the results of an interview with (Ifah \& Mahfud, 2021) at his residence in Dusun Kedungdadap RT 004 Rw 001 Rejamulya Village, Kedungreja District, there are several halal foods which include soy-based ingredients which are used as food for daily needs such as "soybeans" and "tempeh triangle ", Quail Eggs in order to improve the economy of the local community. In addition to Halal food, legumes such as soybeans can be used as a number of foods that make the community's economic potential, including soy pudding, soybean dregs nuggets, kinako bread, soybean cheetos, soy milk, sticky rice powder, soybean pelas, and gruel. sum soy milk (brilio.net $\&$ Pangesthi, 2020).

Tempe Triangle which has a unique philosophy where the triangle illustrates that there are three "angles of the universe" namely meilputi (lahi and life and death). When we eat this triangular tempeh, we should be able to make dhikr and remember the meaning of the process in this life. Tempe is also included in the four healthy five perfect foods as proclaimed by Prof. Poerwo Soedarmo in 1952 AD related to the concept of "Four Healthy Five Perfect" which was popularized and popularized by the Father of Indonesian Nutrition, Prof. Poerwo Soedarmo in the range of 1952 AD which is now no longer used, so that in the era of the Kininan (era of the Industrial revolution 4.0) it has now developed rapidly and been refined back to become a balanced nutrition guide or abbreviated (PGS) (kemkes.go.id, 2016).

As stipulated in Chapter I pasa 1 of Law No. 33/2014 concerning the guarantee of halal products, it is explained that "Products" are goods and / or services which are included in 1) food, 2) beverages, 3) drugs, 4) cosmetics, 5) chemical products. ,6) biological products, 7) genetically engineered products, 8) as well as goods that can be utilized (used, used, or utilized) by the community. Furthermore, in Article 1 Point 2 it is explained related to "Halal Products", namely Products that have been declared "halal" in accordance with Islamic law. Article 1 point 3 is related to Halal Product Process, hereinafter abbreviated to (PPH), which is a series of activities to ensure the halalness of a Product which includes the provision of materials, processing, storage, packaging, distribution, sale and presentation of the product. Then in article 1 point 4) related to materials are elements that will be used to make or produce a product. And finally in article 1 point 5 ) in the case that the Halal Product Guarantee is abbreviated (JPH) is a legal certainty of the halal level of a Product as evidenced by the existence of Halal Certification. Thus, in the Kedungreja sub-district, halal food in the form of halal food has a great potential for the welfare of the local community's economy through this halal food. Another potential is related to the halal food in Muntaha's Puyuh Egg, for example, can be an example in boosting the economy of the community in the Kedungreja sub-district, Cilacap district, Central Java. 


\section{Potential of Halal Food in Wangon District, Banyumas Regency}

Based on the results of an interview with Mr. (Waluyo, 2021), a resident of the wangon subdistrict, Windunegara Village RT 01 RW 06 Kec. Wangon Banyumas, Central Java regarding the Potential of Halal Food in Wangon District in the Era of the Industrial Revolution 4.0, which includes Fried Getuk typical of Banyumas, Mendoan, and traditional ciu. The center of Getuk Goreng Banyumas is in Sokaraja, Banyumas Regency, Central Java. The typical Banyumas Ciu, as expressed by the Head of Wlahar Village, Mr. Narsim, told of producing Ciu in the village of Wlahar Wangon, where this ciu has a long history. The making of ciu, from a hereditary story he heard, began when many Dutch East Indies colonial workers worked in Wlahar. Long story short, residents were taught to make ciu, which at that time was said to be a body-healthy herb. The production of ciu itself, which is usually made by residents, only reaches a maximum alcohol content of 55 percent. In 2007, said Narsim, Wlahar's ciu production was struggled to become bio ethanol. Experimentation was carried out from 30 liters of ciu with a content of 30-35 percent and was refined into 5 liters so that the alcohol content increased to 80 percent. The basic ingredients are brown sugar / Javanese sugar per / $50 \mathrm{~kg}$, then $2 \mathrm{~kg}$ of tape, 24 yeast seeds. Later it will be a 200 liter deep water bath. When used as bio ethanol, there is a lot of shrinkage. So that the selling price becomes expensive. Ciu is also often used for massage fluids. The use of ciu for massage was once promoted as "Tirta Brahma". This promotion was admitted by Narsim to change the negative view of ciu, which is identified as drinking to get drunk. By monitoring ciu as an ingredient for Hand Sanitizer in the midst of the Corona outbreak, Narsim believes that Wlahar's signature product at least has its benefits for a wider audience. Ciu, which contains 80 percent alcohol, can at least be used as an ingredient for hand sanitizing gels and other benefits for maintaining health. he is grateful that locally made products from Wlahar residents can be beneficial for the health of many people and fight the spread of disease (Narsim \& Abdul Aziz (Rep), 2020).

In a study researched by (Waharini \& Purwantini, 2018) related to the development of the halal industry will be more competitive with the involvement of the financial industry and Islamic banking sectors. This study aims to explore the role of Islamic banking in the development of the halal food industry in Indonesia. So as a result, the role of Islamic banking is not only limited to sharia-based financing that is free of usury (interest), maysir (uncertainty), and gharar (gambling). But also at all stages of the production process (halal value chain management). An important role that Islamic banking can play in developing and improving the halal food industry, including in the three halal integrity processes. The first is at the halal control stage, the second is in the logistical process and finally the halal verification stage.

As stipulated in Chapter I pasa 1 of Law No. 33/2014 concerning the guarantee of halal products, it is explained that "Products" are goods and / or services which are included in 1) food, 2) beverages, 3) drugs, 4) cosmetics, 5) chemical products. ,6) biological products, 7) genetically engineered products, 8) as well as goods that can be utilized (used, used, or utilized) by the community. Furthermore, in Article 1 Point 2 it is explained related to "Halal Products", namely Products that have been declared "halal" in accordance with Islamic law. Article 1 point 3 is related to Halal Product Process, hereinafter abbreviated to (PPH), which is a series of activities to ensure the halalness of a Product which includes the provision of materials, processing, storage, packaging, distribution, sale and presentation of the product. 
Then in article 1 point 4) related to materials are elements that will be used to make or produce a product. And finally in article 1 point 5) in the case that the Halal Product Guarantee is abbreviated (JPH) is a legal certainty of the halal level of a Product as evidenced by the existence of Halal Certification. Thus, in Wangon sub-district, halal food in the form of halal food has a great potential for the welfare of the local community's economy through this halal food. Another potential is related to the halal food in Getuk Goreeng which is a characteristic of the traditional food of Banyumas Regency, Central Java, which can be an example in boosting the economy of the community in the wangon subdistrict, Banyumas district, Central Java, Indonesia. And is expected to be an example in other districts in Indonesia.

\section{Ecosystem Driving the Community Economy in Lakbok District through Halal Food}

MES or the abbreviation of Masayarakat Sharia Economy which is a community organization that is expected to be consistent as a locomotive for the development of Islamic economics in Indonesia and become a driving force in an effort to strengthen the community's commitment in building a superior and sustainable Islamic economic ecosystem. The purpose of this MES is to develop domestic and foreign halal industrial markets, develop the national Islamic finance industry, friendly investments involving regional entrepreneurs, and sustainably develop the Islamic economy from rural areas, which are expected to increase partnerships between entrepreneurs (Amin, 2021).

Thus, the Islamic economic community which is the driving force of the economy is the people in the Lakbok sub-district itself. Forms of movement that occur include food security in halal food in the form of halal foods developed by the lakbok community to meet their daily needs, for example by producing Saleh chips like Mother (Baringah, 2021). The ecosystem in the Lakbok Community is actually more in the field of agriculture, but it does not rule out the development through various innovations from various kinds of traditional foods from a long time ago that have been developed until now, such as Cimplung / kulub whose basic ingredients are from cassava. Cassava itself in Javanese comes from the word "budin" which means "Sak Budine" which means anything can be made without any limitations / exploration from the food maker (Kasmuri \& Fikri, 2021). Both from cassava, cassava, or cassava (Manihot esculenta) are tropical and subtropical annual shrubs of the Euphorbiaceae tribe. The tuber is widely known as the staple food for producing carbohydrates and the leaves as vegetables (Wikipedia, 2021).

In the case of the projection of the "halal industry" in the new normal era, for example, which is potential in accordance with the conditions, opportunities, and government efforts in economic development in the new normal era. So in this new habit era, the government, business people, and society can adapt to new economic patterns in order to advance the economy in the new normal era (Kamila, 2020). In addition, in research (Nasrullah, 2018) in analyzing the potential of "industrial halal products" for business actors in Indonesia, this is considering "halal products" which are experiencing rapid development amid the increasing religious tendency of Indonesian society and on the other hand the population. Muslims in the middle class income have increased, so there is an increasing demand for halal products. So that the potential that becomes a need for Halal products (goods and services). There is also "Diversity of Halal Products" and a complete Legal Framework. as well as the existence of "Executing Business opportunities in the Halal Product Market". And look at the existing 
export needs for halal products. So that in the lakbok sub-district in the future challenges in the era of Industry 4.0, the existence of the need for market share, as the results of interviews with (Hamid \& Tusiem, 2021), residents of Lakbok sub-district, Ciamis Regency, can send their sons and daughters from undergraduate to doctoral level by relying on one of them is entrepreneurship in the production of brown sugar / coconut juice juice obtained in such a way.

This is similar to research by (Rachmat, 2016) Coconut sugar as one of the brown sugars plays a role in the food industry, both at the home industry level, small to large scale industries. The market opportunities for brown sugar / coconut are very open, both for the domestic market and for the export market. Coconut sugar business continues to grow, but is still limited in Java and in some areas where people come from Java and especially in areas where alternative employment opportunities are relatively limited. Utilization of the coconut business for coconut sugar has grown especially with the drop in prices for copra and fresh coconut. In rural areas, the impact on coconut sugar entrepreneurs is a family activity (productive), it plays a significant role in providing added value from coconut and a source of family income. From the case in Ciamis and Blitar districts, for example, "coconut sugar" entrepreneurs can provide income between 1,680 rupiah, up to 5,140 rupiah per day for coconut owners and between 1,919 rupiah and up to 3,460 rupiah per day for tapping workers. In addition, the obstacles that arise in the development of "coconut sugar" are in the process of producing it, namely, firstly, the limited workforce who wants to tap (extract coconut juice); second, the existing market system for "brown sugar", and third, regarding the availability of fuel. The possibility of exploiting superior coconut or early coconut such as hybrid coconut which is relatively easy to "tap" (extracting coconut juice water) is an alternative in the development of "brown sugar". Research support in this direction is needed.

Another research by (Nurmaydha et al., 2018) is in the case of "Islamic tourism" which is a "new trend" of tourism in the world. The opportunities that exist in Islamic tourism have the potential to be very profitable. Islamic tourism in Indonesia itself accommodates many industries, such as "halal food", "halal restaurants", and also "sharia hotels". One of the aspects that must be done in order to make the certification "sharia hotel" smooth is a restaurant that is "halal certified". Thus it does not rule out that in several cities and districts throughout Indonesia, both halal food must have halal certification from the MUI, it does not rule out the possibility of certification products in the lakbok sub-district, Ciamis district, so there is a need for understanding related to Halal Food, and also tourism. sharia.

Another research by (Nurmaydha et al., 2018) is in the case of "Islamic tourism" which is a "new trend" of tourism in the world. The opportunities that exist in Islamic tourism have the potential to be very profitable. Islamic tourism in Indonesia itself accommodates many industries, such as "halal food", "halal restaurants", and also "sharia hotels". One of the aspects that must be done in order to make the certification "sharia hotel" smooth is a restaurant that is "halal certified". Thus it does not rule out that in several cities and districts throughout Indonesia, both halal food must have halal certification from the MUI, it does not rule out the possibility of certification products in the lakbok sub-district, Ciamis district, so there is a need for understanding related to Halal Food, and also tourism. sharia. 
Thus, the Islamic economic community which is the driving force of the economy is the people in the Lakbok sub-district itself. With the development of food-making practices carried out in their respective homes, it only remains to prepare the ingredients and then make it a typical regional food, then proceed to legalizing companies for those who are already advanced, or can also sell a halal food product such as Mr. Mr. (Sarikun, 2021) collectors sell the production of brown sugar / Javanese sugar. In his statement Mr. (Hamid \& Tusiem, 2021) has started producing this brown sugar from 2005 un til now (2021) is still running, and from the results of the production of brown sugar which is sold to collectors, he is able to finance his sons and daughters from school to graduate school, even from the proceeds. The sale of this brown sugar product which is only sold to collectors is enough to help finance up to university to Doctoral level. Furthermore (Kasmuri \& Fikri, 2021) in their daily life the main job is a real farmer, but in addition to farming they always plant cassava in their garden, besides that there is also ganyong (a kind of tubers), then red yams, bulbs, and so on. to be used as a side job, where when the rice is not harvested, it can take advantage of the harvest from cassava, sweet potato, muntul and others to meet their daily needs. Ibu (Baringah, 2021) is also a farmer, but her main focus is the pious banana chips business in meeting her daily needs without giving up her farming work. Likewise Mr. (Jembrang, Soleh and Taufiq, 2021) in his daily life the main job is picking young coco nuts and old coconuts. However, they did not leave their farming work. Similar to what was conveyed by the father (Amar, 2021) and his wife every day he opens his fried food stall to cover his daily needs without leaving the farmer's job.

As a result, it can be concluded that the ecosystem that drives the economy in the Lakbok sub-district is a farmer on average, but it does not rule out the possibility of producing / producing halal food as a booster for the economy in the Lakbok area, Ciamis Regency. However, in the case of halal adhesion, the products produced do not all include halal labels.

\section{Ecosystem Driving Community Economy in Wangon District through Halal Food}

As for the ecosystem that drives the community's economy in the wangon sub-district through Halal Food, it is actually very important in order to reduce public anxiety regarding a number of products in the form of drinks or food that are considered illegitimate, or less halal. This means that part of the driving force of the community's economy in the Wangon sub-district is in the business of making certain foods / drinks and then selling them to cover their daily needs. As mentioned above, it is related to MES, whose goal is to become a Sharia Economic Community that can consistently be the locomotive of sharia economic development in Indonesia and become a driving force in an effort to strengthen community commitment in building a superior and sustainable sharia economic ecosystem. In addition to developing the Islamic economy, the purpose of MES itself is to develop the halal industrial market both at home and abroad, development of the national Islamic finance industry, friendly investment involving regional entrepreneurs, and sustainable development of the Islamic economy from rural areas, which are expected to increase partnerships between entrepreneurs with each other.

Based on the results of interviews related to the Halal Food Challenge in Wangon District in 4.0 as it is now, according to his opinion (Waluyo, 2021) he said that in an era like now where the era is progressing, millennial children (young people / i) have moved to another 
liver related to traditional food which is used as typical food in certain locations, for example in the wangon sub-district, Banyumas district, Central Java province. The following are excerpts of the results of interviews with resource persons: the challenge is the development of times, so traditional food is less desirable, this is because young people in a sophisticated era like today (4.0) prefer food made by foreigners (Waluyo, 2021). For example, halal food in the Province of Bali, Indonesia where the results of this research by (Faraudis et al., 2019) show that storing "halal" and "non-halal" ingredients in one place and each "ingredient" (halal and non-halal) halal) will be made in "one container" according to the category and type of ingredients, in a condition that approximately (91.7) percent of customers in the restaurant "Spice Beach Club Bali" will order dishes that are categorized as "halal". So that what is in the food at the Spice Beach Club Bali is most of the food menu with a "halal menu". Thus it does not rule out that in several cities and districts throughout Indonesia, both the halal food industry must have halal certification from the MUI, it does not rule out the possibility that certification products in the wangon sub-district, Banyumas district, also need understanding related to Halal Food, and also Islamic tourism. In order to support the potential that exists in the region, which incidentally has a Muslim majority population.

Meanwhile, the challenges that exist in Wangon District are related to halal food, the absence of legalization in the halal food it has made, for example the products owned by the mother producer (Rempi, 2020) as reported by news.detik.com (Arnbi Anugrah) where the results of ciu production are typical of the village. The village (Wlahar, Cikakak, Windunegara) Wangon Banyumas District, Central Java does not have a halal certification as stated by (waluyo, 2021) he said that: Ibu Rempi, who is one of the producers of traditional drinks, named "Ciu", if this Ciu is labeled as halal from the MUI, it is like the world has turned upside down, halal food is forbidden and haram food is permissible such as the ciu made by Mrs. Rempi. In essence, the halal melting of the "ciu" drink among the community, especially in the wangon sub-district, has not been able to accept it, this is because Ciu is included in the category of a safe drink and this ciu drink is the same as alcohol which can intoxicated people who drink it when drinking excessively.

Thus, there has been no halal amalgamation by the local MUI, namely in the wangon subdistrict related to the smelting of halal food in the form of "ciu" drinks due to several factors, including according to the researchers' opinion, after conducting an analysis related to the lack of awareness of the importance of halal melting in halal food. And also the lack of outreach by the local MUI regarding the guarantee of halal products as stated in Chapter I pasa 1 of Law No. 33/2014 concerning the guarantee of halal products which is clear that "Products" are goods and / or services included in 1) food, 2) beverages, 3) medicine, 4) cosmetics, 5) chemical products, 6) biological products, 7) genetically engineered products, 8) as well as goods that can be utilized (used, used, or utilized) by the community. Furthermore, in Article 1 Point 2, it is explained related to "Halal Products", namely Products that have been declared "halal" in accordance with Islamic law.

Thus the sharia economic community which is the driving force of the economy is the people in the Wangon sub-district itself. With the development of food-making practices carried out in their respective homes, it only remains to prepare the ingredients and then make it a typical food for the area, then proceed to legalizing companies for those who are 
already growing rapidly, or can also sell other halal food products such as Mr. (Waluyo, 2021) opened a business to become a reseller of Getuk Lindri Khas Banyumas, he took it directly from Purwokerto Banyumas then sold it back in the wangon sub-district. Getuk lindri / getuk fried typical of Banyumas is already labeled halal, and until now it is very popular, especially the Banyumas area. Mrs. Rempi, for example, produces Ciu which is the hallmark of Banyumas district which is now being glimpsed by the Banyumas Regent Husein to be used as a hand sanitizer in order to prevent the spread of the corona 19 virus. However, Ciu is identical to an intoxicating drink by the community which still seems negative. In Wlahar Village, Cikakak, and Windunegara Village, Wangon Subdistrict, starting in 1942, they have been producing liquor, which is a traditional Banyumas drink (Setya, 2020). The relation with halal food in becoming an economy boosting ecosystem for the local community, especially in the wangon sub-district, wants to stay there is a need for halal melting in the ciu products, but until now this has not happened because there is still a community stigma about the haram of ciu.

In the business that is carried out by (Waluyo, 2021), namely becoming a resseler of Banyumas fried getuk, there are more and more enthusiasts due to its unique characteristic of this one typical Banyumas food. In addition, Waluyo also works as a farmer, but his focus is more on doing business in the culinary field, especially halal food to meet his daily needs. As a result, it can be concluded that in relation to the economic driving ecosystem in the wangon sub-district, the average person is a farmer, but it does not rule out the possibility of producing / producing halal food as an economic booster in the wangon area, Banyumas Regency. However, in the case of halal adhesion, the products produced do not all include halal labels. An example is Ciu which is characteristic of the villages of Wlahar, Cikakak and Windunegara, Wangon Subdistrict, where this ciu production can boost the economy of local residents.

\section{Ecosystem Driving Community Economy in Kedungreja District through Halal Food}

The ecosystem created by the people in the Kedungreja sub-district as a driving force for the economy of the local community is carried out by producing Halal Food foods, such as mendoan, or fried triangular tempeh, quail eggs, fried quail and so on (Ifah \& Mahfud, 2021). Another thing that can be done with the many culinary business opportunities in the present era is no exception in neighboring sub-districts, namely in Sidareja sub-district, Cilacap district, there is a culinary tour with the name "Mbah Suro" by having its own mainstay menu that can be included in the halal food category which includes: Grilled fish such as "Gurame Fish", "Pomfret Fish", Mujaer Fish, Catfish, Goldfish, there are also "Village Fried Chicken" and "Village Grilled Chicken". Sea food Fried and grilled duck which is super tasty. Rib and oxtail soup Miniman sweet tea, hot tea, Alpuket juice (various juices), (Serbandeso.com. 2019). As quoted from kodesjabar.com) this restaurant "mbah suro manganti" is also a "floating culinary tour" in Cilacap district with a complete address at Jalan Dam Manganti RT 01/02 Bojongsari Kedungreja, Bojongrongga, Kedungreja, Cilacap Regency, Central Java.

In terms of the formation of an ecosystem created by the people in the Kedungreja subdistrict to boost the economy of the local community, of course there are several challenges it faces. Based on the results of interviews related to the challenges of halal food in Kedungreja Subdistrict in Era 4.0, as Mr. friendly, besides that only eggs are selling well on 
the market. For example, what happened in Kedungreja sub-district, Cilacap district, Central Java Province. The following are excerpts of the results of interviews with informants who say that: With the presence of traditional food in the Kedungreja sub-district which is included in the halal food category, in general, it is still less attractive because the price of halal food such as quail eggs has soared in the market. People in the kedungreja sub-district prefer to buy cheaper and instant halal food such as fried chicken at a price of Rp. 6000 instead of buying quail eggs which cost Rp. 7500 to Rp. 8000 . However, many people in rural areas or areas need, for example, for wedding purposes for the banquet of invited guests who are present, and usually buyers of small stalls such as "angkringan", small shops in the market.

Thus, the obstacles or challenges in the Kedungreja sub-district include the lack of public interest in "halal food" because the price is quite high compared to their daily needs. Apart from that, the economic factor is also the same, where people only buy the products needed for daily consumption such as eggs and vegetables and other food staples. Mrs. Ifah as the wife of Mr. Muntaha Mahfud, one of the figures in Sidareja sub-district took the initiative to make various handicrafts and opened a business by utilizing halal food in the form of quail eggs and quail meat, such as quail eggs which in fact are halal food that can be used to decorate complementary foods. Meanwhile, quail meat can be consumed for consumption like fried chicken, but this quail meat has a slightly tough texture, but if it is fried with special spices, the taste value is not inferior to other chicken meat. Apart from eggs that can be sold in the market, quail meat can also be consumed, but it is not yet common to be used as a mainstay menu in the stalls. However, Ifah and Mahfud are still trying to develop this halal food business to boost their economy. Evidence from halal food that can boost the people's economy is the fulfillment of daily needs, and this has been proven by Mr.Muntaha Mahfud and Ifah to be sufficient for life.

\section{Analysis of the Potential of Halal Food in Lakbok, Kedungreja, and Wangon Districts as Ecosystems Driving the Community's Economy}

Opinion (Muttaqin, 2018) regarding halalness is an important element in making economic decisions for Muslims. Halalness does not only refer to the material (dhat), but also to the possessions. Divine guidance (revelation) in the form of hadith has an important role in determining halalness. Imam Bukhari said that between halal and haram is a vague matter (umurun musytabihatun), so it must be avoided. Meanwhile, the history of Tirmidhi states that between halal and haram are matters that are forgiven (mimma 'afa' anhu), so that it is permissible to do so. In this case related to the type of halal food or halal food in Lakbok, Kedungreja, and Wangon Districts as a form of Ecosystem Driving the Community's Economy, it is substantially halal, but related to halal melting and Halal Certification of traditional food in the three sub-districts, not all of them are certified. This is in line with the research proclaimed by (Hidayatullah, 2020) that in the amalgamation of halal food it can bring out confidence and certainty in the halalness of a food as well as a form of caution that will prevent consuming foods that are haram in the stigma of society, especially in Indonesia. Halal auctioning and halal certification can also affect the selling value of products circulating in the market (Ramlan \& Nahrowi, 2014). In addition, with the existence of halal certification if applied in business, ethically it is a form of Islamic values where the value of its benefits is to protect consumers from consuming halal food for Muslims, 
meaning that Muslim people who eat food labeled halal have a high level of consumer confidence ( Warto \& Samsuri, 2020).

In terms of halal politics too, meaning in "halal politics" as in research (Septiadi et al., 2020) to prevent fake news or hoaxes in the community is also needed, exemplified in his research in fake news in election cases. Thus, as a form of effort in establishing an Economic Driving Ecosystem for local communities in Lakbok, Kedungreja, and Wangon Districts, it is necessary to strengthen halal food products so that the marketability value increases due to the smelting and halal certification where this halal attachment to food can prevent elements of halal lying. whether or not a certain food product, especially in the three districts. Another research launched by (Madusari \& Wibowo, 2018) by linking the potential that exists in fisheries and marine, where a product that has been produced and has a good market share is in the form of food such as agar, jelly, natural dyes which are very much needed as an ingredient. the basis for further processing so as to produce sustainable, healthy and halal food, medicinal and cosmetic products. In controlling market share, it can also be done through producing foods that are labeled halal (Wibowo \& Madusari, 2018).

Producers who are aware of the needs of society have their own way of attracting consumers. One of them is the label, which is a characteristic for certain products so that they will be remembered in the hearts of the people. Indonesia, in the face of regional, international and global free trade, is feared that it is being flooded with food and other products that contain or are contaminated with haram elements. In processing, storage, handling, and packaging techniques, preservatives that are harmful to health are often used or additives that contain haram elements which are prohibited in Islam. Imported products are now starting to flood our homeland with various types of attractive packaging. People need to be careful in choosing these products, there could be something hidden behind these food products that are not suitable for consumption by Muslims. For Muslims, mistakes in choosing food products that are consumed can cause physical and mental harm, physically consuming products that contain hazardous materials can harm health, while mentally consuming products that are not halal can cause sins, with the inclusion of halal labels, Muslim consumers are protected. especially in these sub-districts (wangon, Lakbok, and also Kedungreja) the majority are Muslims. Inclusion of the halal label as a means of information from producers to consumers about the products they will sell. So that consumers really know what ingredients are used, including the additives listed on the packaging. Correct labeling in accordance with applicable regulations will establish the creation of honest and responsible trading. So that it will facilitate the supervision of food safety and protect consumers from wrong perceptions. Halal labeling plays a role in increasing sales to attract consumers, especially Muslim consumers, where the purchase decision can serve as a measure of the extent to which the level of sales of products that have been halal has been determined with products that are not clear between halal and haram, especially in the districts of Wangon, Kedungreja and Lakbok.

Research conducted by (Missiati, 2019) in his journal shows that Cilacap Regency has a large enough tourism potential to be developed into "sharia tourism". This is evidenced by the indication of a community that understands "sharia tourism" where tourism is carried out with the aim of tadabbur nature and recreation, in addition there is the concept of "family tourism" which is in accordance with the fatwas of the National Sharia Council and the 
Indonesian Ulama Council (MUI). Regarding tourism activities and the location of tourism objects, it is quite possible to avoid immoral activities, there is only a little that needs to be addressed, namely the application of regulations on no dating and the implementation of a more stringent curfew.

Research by (Mahardika, 2020) found that the marketing strategy in halal tourist destinations is a form of culture-based tourism that requires values and Islamic Sharia until finally what is needed is the emergence of a personality with noble character as its basic foundation. As a new concept of halal tourism in the tourism industry, of course, sharia tourism needs further innovation and development as well as a deep and comprehensive understanding of the collaboration of Islamic values offered so that halal tourism activities can be exposed by the public (non-Muslims). Therefore, in the three sub-districts, namely (Wangon, Lakbok, and also Kedungreja) the researchers conducted as the object of this research location where the majority are Muslims, so this can be used as one of the markets for the halal tourism industry in the form of the largest halal foods in the world. , which is in accordance with what was conveyed by (Thohir, 2021) as Minister of BUMN and Chair of the Sharia Economic Community (MES) at the inauguration of the Nurul Quran Pesantren Pertashop in Surusunda Village, Karangpucung District, Cilacap Regency (Republika.co.id, 2021 ). This means that the potential of the halal industry that can be used or developed by Indonesia does not rule out the possibility that it can be carried out by three sub-districts namely Wangon, Lakbok and Kedungreja through the implementation of halal food. So that the three sub-districts can indirectly contribute to increasing state revenue through consolidation and halal certification and are also Muslim friendly. This means that if the three sub-districts are able to carry out halal amalgamation and halal certification on halal food, they can open up opportunities to increase state income through a Muslim-friendly tourism sector.

Information presented online or online at this time is the main influence in terms of decision making by consumers in this case tourism service users in almost all major market segments, therefore e-marketing is expected to be able to create a path or method as an appropriate product marketing strategy useful in providing efficient and effective information for potential consumers (Nengsih \& Suryani, 2019). For this reason, all information conveyed by producers in the three sub-districts, namely wangon, lakbok and kedungreja, must use unique and interesting marketing strategies, such as marketing through social media, Facebook, Instagram, YouTube, Instagram, and so on.

Opinion (Susihono et al., 2018) regarding products that have been certified as halal can circulate in various regions in Indonesia, on condition that there must be approval from the LPPOM MUI (Institute for the Study of Food, Drugs and Cosmetics, the Indonesian Ulema Council) The raw materials used by producers are part of the obligation to be registered in the raw material matrix form without exception. This is one of the obstacles for producers in the wangon, lakbok and kedungreja sub-districts regarding the guarantee of legal certainty, which matters relating to smelting and halal certification need to be registered with LPPOM MUI. While the challenges that exist in Lakbok District are related to halal food, the abse nce of legalization in the halal food it has made, for example the products owned by the producer father (Hamid \& Tusiem, 2021) where the brown sugar production does not have halal certification due to several factors, including due to awareness of the importance of 
halal melting of the food which is produced by private production. And also the lack of outreach by the local MUI regarding the guarantee of halal products as stated in Chapter I pasa 1 of Law No. 33/2014 concerning the guarantee of halal products which is clear that "Products" are goods and / or services which are included in 1) food, 2) beverages, 3) medicine, 4) cosmetics, 5) chemical products, 6) biological products, 7) genetically modified products, 8 ) as well as goods that can be utilized (used, used, or utilized) by the community. Furthermore, in Article 1 Point 2 it is explained related to "Halal Products", namely Products that have been declared "halal" in accordance with Islamic law.

Research by (Pujiono et al., 2018) in Central Java province as an integral part of the Indonesian state has great potential in the form of halal Micro, Small and Medium Enterprises (MSMEs) in supporting development. Strategies that can be developed to increase the competitiveness of halal MSMEs in Central Java are increasing halal UMKM certification, improving halal MSME HR qualifications, using modern and appropriate technology to meet halal UMKM product standards, strengthening linkages with industry (downstream), diversifying products. Halal UMKM, Increase the role of religious and educational institutions for the literacy of halal UMKM products to the Muslim community, increase the role of fintech for financing and certification of halal UMKM products and their marketing, build synergies with related institutions for halal UMKM product innovation, increase branding of halal UMKM products through technology media and information, strengthening fiqh studies to produce halal UMKM products. Therefore, in the Kedungreja sub-district, the importance of smelting and halal certification on halal food in the Kedungreja sub-district needs to be done, but the reality in the field is that there is an understanding of the community about the importance of this halal amalgamation, which has enormous benefits, namely it can increase the branding of existing MSME products. in the kedungreja district. Responses (Mahfud \& Ifah, 2021) related to MSME businesses that need verification as halal UMKM products are still lacking in demand in the community, this is due to a lack of understanding of the community and quite expensive management costs. Moreover, the lack of public interest in "halal food" is because the price is quite high compared to their daily needs. Apart from that, the economic factor is also the same, where people only buy the products needed for daily consumption such as eggs and vegetables and other food staples (Mahfud \& Ifah, 2021).

As stated by Ahmad Ali Khujazi, one of the students of Sharia Economics, Bogor Agricultural University in an article published on Suarajelata.com on April 24, 2020, it was explained that the strategy to support the halal food industry in Indonesia is to collaborate between stakeholders, coordination and synergy between banks. Indonesia (BI), the Government, and Sharia Financial Institutions (LKS), improve competitiveness, and also halal certification. The next thing is similar in terms of halal economic actors in Indonesia from various growing halal sectors such as food and beverage, tourism, cosmetics, pharmaceuticals, media and recreation and will also become a separate brand in Indonesia (Vnews, 2020) in the State Islamic Economy Report event. 2020/2021 in Jakarta.

From the explanation of the analysis of the potential for halal food produced by the community (producers) in the lakbok, kedungreja, and wangon districts as an ecosystem that drives the economy of the people of the region above, halal food can be used as a means of contribution in boosting the economy of the people in the three sub-districts. In 
addition, the majority of the people in the three sub-districts are mostly occupied by Muslims, so this can bring out the great potential of the selling value of the products produced by the rampant halal food spread on the market. The potential of Halal Food in Lakbok, Kedungreja, and Wangon Districts as a form of Ecosystem Driving the Community's Economy is very diverse, but related to the consolidation and halal certification of halal food in the three districts, not all have done this, this is due to several factors, including the level of understanding of the community who there is still minimal importance to the merger and halal certification, then the cost of submitting an expensive certification, as well as the lack of consumer interest in buying halal food products due to the fact that the public is still hesitant in determining the purchase of halal products but rather expensive, or choosing products that do not have a halal label and certification.

\section{Conclusion}

Based on the above discussion and description related to the de scription of local specialty foods that have the potential to become halal food (halal food) to boost the economy of local communities in three areas including Lakbok sub-district, Kedungreja sub-district, and Wangon sub-district above, it can be concluded that the halal food sector or halal food in Indonesia, especially in the era of 4.0 as it is now has become a necessity. This is because 1 ) Indonesia is one of the largest Muslim population in the world. 2) traditional regional specialties also need to be developed in order to boost the economy of the local community. 3) Support from the government in an effort to make Indonesia the world's halal center. 4) If the potential of the halal industry is not developed, it will become a threat to the Indonesian economy. Therefore, the preservation of halal food produced from traditional foods in the three sub-districts can fulfill the daily needs of the local people. In addition, by preserving halal food, the people in the three sub-districts indirectly contribute to the economic boosting ecosystem of the local communities in the region, this is evidenced by the fulfillment of their daily needs. The various foods that can be used as halal food in these three sub-districts are various, including from the form of traditional food made from cassava including chips, Tape, Cimplung or Kulub and also Ciu, from soybean ingredients including Sule and Tempe Mendoan, from legen ingredients (water coconut juice) can be made into palm sugar / brown sugar and can also be used as a mixture for making apem / cake food. However, from the potential of halal food, some are already labeled halal and some are not labeled halal. This is what makes halal food in these three sub-districts less attractive to consumers.

\section{References}

Ahdiati, Triana. 2020. "Kearifan Lokal dan Pengembangan Identitas untuk Promosi Wisata Budaya di Kabupaten Banyumas." Jurnal Pariwisata Terapan 4 (1): 25-34. https://doi.org/10.22146/jpt.50417.

Ahyani, H., Muharir, \& Ulya, W. (2021). Potensi Wisata Halal Kota Banjar, Jawa Barat di Era Revolusi Industri 4.0. Tornare: Journal of Sustainable and Research, 3(1), 4-12. https://doi.org/10.24198/tornare.v3i1.31511

Ali, M. (2016). Konsep Makanan Halal dalam Tinjauan Syariah dan Tanggung Jawab Produk Atas Produsen Industri Halal. AHKAM: Jurnal Ilmu Syariah, 16(2), 291-306-306. https://doi.org/10.15408/ajis.v16i2.4459 
Dewi, N. S. A. A. (2020). Kajian Kesadaran Konsumsi Pangan Halal Pada Pelajar SLTP. Indonesia Journal of Halal, 3(1), 69-73. https://doi.org/10.14710/halal.v3i1.8383

Djakfar, Muhammad. 2017. Pariwisata halal perspektif multidimensi : peta jalan menuju pengembangan akademik \& industri halal di Indonesia. Malang: UIN-Maliki Press. http://repository.uin-malang.ac.id/2422/.

Faraudis, Z., Andiani, N. D., \& Rahmawati, P. I. (2019). Bingkai Halal dan Non Halal: Studi Kasus Penerapan Halal Food di Restoran Spice Beach Club Bali. Jurnal Manajemen Perhotelan dan Pariwisata, 2(2), 72-80. https://doi.org/10.23887/jmpp.v2i2.22092

Farid, M., \& Basri, H. (2020). The Effects of Haram Food on Human Emotional and Spiritual Intelligence Levels. Indonesian Journal of Halal Research, 2(1), 21-26. https://doi.org/10.15575/ijhar.v2i1.7711

Hervina, H. (2017). Trend Halal Food di Kalimantan Timur. FENOMENA, 9(2), 175-186. https://doi.org/10.21093/fj.v9i2.1295

Hidayatullah, M. S. (2020). Sertifikasi dan Labelisasi Halal Pada Makanan dalam Perspektif Hukum Islam (Perspektif Ayat Ahkam). YUDISIA : Jurnal Pemikiran Hukum dan Hukum Islam, 11(2), 251-270. https://doi.org/10.21043/yudisia.v11i2.8620

Kamila, Evita Farcha. 2020. "Peran Industri Halal Dalam Mengdongkrak Pertumbuhan Ekonomi Indonesia Di Era New Normal.” LIKUID: Jurnal Ekonomi Industri Halal 1(1). https://journal.uinsgd.ac.id/index.php/likuid/article/view/9995

Madusari, B. D., \& Wibowo, D. E. (2018). Potensi dan peluang Produk Halal Berbasis Rumput Laut. Indonesia Journal of Halal, 1(1), 53-57. https://doi.org/10.14710/halal.v1i1.3112

Murti, Tridjoko Wisnu. 2017. "Halal Life Style And Global Trade." International Seminar on $\begin{array}{lllll}\text { Tropical Animal } & \text { Production (ISTAP) } & 0 & (0):\end{array}$ 39.https://journal.ugm.ac.id/istapproceeding/article/view/30115

Muttaqin, A. A. (2018). Konsep Penentuan Halal Dalam Ekonomi Islam (Studi Komparasi Hadits Riwayat Bukhari dan Tirmidzi). Indonesia Journal of Halal, 1(1), 15-24. https://doi.org/10.14710/halal.v1i1.3111

Missiati, 1423401025. (2019). Potensi Pengembangan Pariwisata Syariahdipantai Teluk Penyucilacap(Perspektif Fatwa DSN MUI Nomor 108/DSN-MUI/X/2016)Tentang Pedoman Penyelenggaraan Pariwisata Berdasarkan PrinsipSyariah) [Masters, IAIN Purwokerto]. http://repository.iainpurwokerto.ac.id/5842/

Mahardika, Rahardi. 2020. "Strategi Pemasaran Wisata Halal." Mutawasith: Jurnal Hukum Islam 3 (1): 65-86. https://doi.org/10.47971/mjhi.v3i1.187

Nasrullah, A. (2018). Analisis Potensi Industri Halal Bagi Pelaku Usaha Di Indonesia. AtTahdzib: Jurnal Studi Islam dan Muamalah, 6(1), 50-78. http://ejournal.kopertais4.or.id/mataraman/index.php/tahdzib/article/view/3406

Nazihah, A., \& Arifin, B. S. (2020). The Impact of Food on Muslims Spiritual Development. Indonesian Journal of Halal Research, 2(1), 27-32. https://doi.org/10.15575/ijhar.v2i1.7870

Nengsih, Ifelda, dan Irma Suryani. 2019. “Membangun ekonomi masyarakat dengan mengembangkan pariwisata halal berkerarifan lokal: peluang dan tantangannya di desa Kubugadang Kota Padang Panjang." Proceeding IAIN Batusangkar 4 (1): 14350.

http://ecampus.iainbatusangkar.ac.id/ojs/index.php/proceedings/article/view/154 $\underline{9}$ 
Nurmaydha, A., Mustaniroh, S. A., \& Sucipto, S. (2018). Strategi Pengembangan Restoran Halal Sebagai Penunjang Hotel Syariah (Studi Kasus Di Unida Gontor Inn, Universitas Darussalam Gontor Ponorogo). Dinar: Jurnal Ekonomi dan Keuangan Islam, 5(2), 71-82. https://doi.org/10.21107/dinar.v5i2.5006

Paskasari, Clara Shinta. 2020. "Kapasitas Kelembagaan Pengelola Desa Wisata Brajan Kabupaten Sleman." Jurnal Pariwisata Terapan 4 (1): 12-24. https://doi.org/10.22146/jpt.48259.

Pujiono, A., Setyawati, R., \& Idris, I. (2018). Strategi Pengembangan Umkm Halal Di Jawa Tengah Dalam Menghadapi Persaingan Global. Indonesia Journal of Halal, 1(1), 1-7. https://doi.org/10.14710/halal.v1i1.3109

Rachmat, M. (2016). Pengusahaan Gula Kelapa sebagai suatu alternatif pendayagunaan kelapa: Studi kasus di Kabupaten Ciamis dan Blitar. Forum penelitian Agro Ekonomi, 9(1), 18-26. https://doi.org/10.21082/fae.v9n1.1991.18-26

Ramlan, R., \& Nahrowi, N. (2014). Sertifikasi Halal Sebagai Penerapan Etika Bisnis Islami Dalam Upaya Perlindungan Bagi Konsumen Muslim. Ahkam : Jurnal Ilmu Syariah, 17(1), Article 1. https://doi.org/10.15408/ajis.v17i1.1251

Sah, S. L. (2018). Halal Kuliner Perspektif Hukum Adat (Analisis Label Halal Pada Makanan Tradisional Nasi Jamblang ). Inklusif (Jurnal Pengkajian Penelitian Ekonomi Dan Hukum Islam), 3(2), 184-196. https://doi.org/10.24235/inklusif.v3i2.3393

Susihono, W., Irhamni, I., Rodani, R., Febriasari, A., Samsudin, S., Khasanah, A. U., Langitasari, I., Wijayanti, I. E., Nurtanto, M., Yuanita, T., \& Nurhayati, N. (2018). Tingkat Penggunaan Bahan Tersertifikasi Halal Berdasarkan Usulan Bidang Audit Kepada Tim Komisi Fatwa Mui Provinsi Banten. Indonesia Journal of Halal, 1(1), 4347. https://doi.org/10.14710/halal.v1i1.3113

Sayyidatunisa, S., Wahidyah, A. I., Alam, M. N., Mayasari, A. E., \& Agya, H. P. (2020). Digitalisasi halal food menggunakan platform design toolkit. Indonesia Journal of Halal, 3(1), 64-68. https://doi.org/10.14710/halal.v3i1.8381 